\title{
The State of Water Management in Ethiopia: Problems and Solution Approaches
}

\author{
Awol Kedir JEWARO ${ }^{1 *}$, İbrahim DÍLER ${ }^{2}$ i \\ ${ }^{1}$ Süleyman Demirel University Institute of Water Sciences, Department of Water Management, 32000 Isparta, \\ Turkey \\ ${ }^{2}$ Isparta University of Applied Sciences Department of Fisheries, 32000 Isparta, Turkey, E-mail:
}

*Corresponding Author: awolkedir25@gmail.com

Received 14 April 2021; Accepted 22 June 2021; Release date 01 December 2021.

How to Cite: Jewaro, A. K, \& Diler, İ. (2021). The state of water management in Ethiopia: Problems and solution approaches. Acta Aquatica Turcica, 17(4), 556-568. https://doi.org/10.22392/actaquatr.915819

\begin{abstract}
Water management is considered to be a field that searches for optimal solutions to the problems posed by society's need for water and the availability of water in nature. Urbanization and rapid increase in population have brought many problems related to water resources, especially in developing countries like Ethiopia. As a result, millions of people do not have access to potable water and improved sanitation. This study found that the main water problems in Ethiopia are more likely to result from weaknesses in coordination, lack of adequate authorized institutions, rapid population growth, technical, financial, and hydro political problems rather than water scarcity. The country's policy on sharing its natural resources, allocation, and management of transboundary water resources creates major problems between upstream and downstream countries. The study recommends advanced management mechanisms and appropriate approaches that can solve the existing problems and promote the socio-economic development of the country.
\end{abstract}

Keywords: Ethiopia, Nile River, Water Allocation, Water Management, Water Resources

Etiyopya'da Su Yönetiminin Durumu: Sorunlar ve Çözüm Yaklaşımları

Özet

Su yönetimi, toplumun suya olan ihtiyacının ve suyun doğadaki mevcudiyetinin yarattığı sorunlara en uygun çözümler arayan bir alan olarak kabul edilmektedir. Kentleşme ve nüfusun hızla artması, özellikle Etiyopya gibi gelişmekte olan ülkelerde su kaynakları ile ilgili birçok sorunu beraberinde getirmiştir. Sonuç olarak, milyonlarca insanın içme suyuna ve gelişmiş sanitasyona erişememektedir. Bu çalışma, Etiyopya'daki asıl su sorunlarının su kıtlığından çok su kaynaklarının koordinasyondaki zayıflıklardan, yeterli yetkilendirilmiş kurumların eksikliğinden, hızlı nüfus artışından, teknik, finansal ve hidropolitik sorunlardan kaynaklanma olasılığının daha yüksek olduğunu bulmuştur. Ülkenin doğal kaynaklarının paylaşımı, sınıraşan su kaynaklarının tahsisi ve yönetimine ilişkin politikası, yukarı ve aşağı havza ülkeleri arasında büyük sorunlar yaratmaktadır. Bu çalışma, mevcut sorunları çözebilecek ve ülkenin sosyo-ekonomik kalkınmasını destekleyebilecek gelişmiş yönetim mekanizmaları ve uygun yaklaşımlar önermektedir.

Anahtar Kelimeler: Etiyopya, Nil Nehri, Su Tahsisi, Su Yönetimi, Su Kaynakları

\section{INTRODUCTION}

Water is considered the elixir of life in the world. It would not be an exaggeration to say that without effective water resource management, the world's social and economic development will be severely constrained or even threatened in the future. Both developed and developing countries need to implement more effective water management policies and practices for better water quality and ensure the availability of water in nature (UNEP, 2010).

According to Prasifka (1994), water covers about three-quarters of the earth's surface. However, it is worth noting that freshwater is unevenly distributed across the world. To illustrate, only the Amazon River carries one-fifth of the water discharged by all the world's rivers. The Amazon is theoretically enough to supply twice the world's freshwater needs. The great river of China, Yangtze Kiang, has enough water to supply every person on the planet with about 500 liters of water in a day.

The Nile, considered the longest river in the world and originating in Ethiopia, is known as the main source of water supply for Egypt and Sudan. With nearly $72 \%$ of the river's potential originating from the highlands of Ethiopia, the issue of exploiting the Nile River is now the focus of interest for 
the Ethiopian government. These concerns are the effect of increasing demand in using the river for various purposes by the Ethiopian government as well as downstream countries, especially Egypt (Bilen, 2009).

Political and social problems will likely arise between the riparian states and Ethiopia as a result of the exploitation of the Nile River (Loucks and Van, 2017). As water is nowadays a limiting factor for the socio-economic development of any country, international, regional, and local conflicts overutilization of water are increasing significantly. In addition to the impact of global change on water resources in the world due to increasing demand, excessive water extraction from underground aquifers and rapid population growth are among these problems.

The issue of cross-border waters has arisen since the earliest time over who owns a body of water, who has a right to use it, or how water should be allocated and shared among those who claim it (Loucks and Van, 2017). The fact that all countries involved in disputes over transboundary waterways have still not signed the 1997 General Convention UN on the Non-Navigational Use of International Waterways is a worrying situation. This case; thus, has some marginal implications for the resolution of current and future water disputes (Schelwald et al., 2009).

Although the increase in water demand in agricultural production has been of great concern worldwide in recent years, the provision of water for energy production is ignored by water professionals and development experts. Sustainable development and advanced economic growth, sanitation, wastewater treatment, and water supply cannot be achieved without adequate energy resources, especially in developing countries. Similarly, it is not possible to produce electricity on a large scale without large quantities of water (Asit, 2008).

Water resources development and management strategies can be considered in terms of economic and non-economic measures. The all-inclusive National Water Management Development (2000) strategy initiated by the Ethiopian government shows more attention to the use of non-economic measures of water demand management than the previous supply-driven plan. It recommends that the use of water tariffs to reduce water demand must be complemented by education campaigns on water conservation and use (MoWR, 2002).

According to WWAP (2012), water management is not only a technical term but also encompasses various scientific disciplines and activities. It requires a combination of practices and measures, including policies, regulations, principles, prices, and other incentives, and changes in physical infrastructure and facilities. Integrated Water Resources Management (IWRM), which is intensively voiced nowadays, focuses on the necessary integration of water management between sectors, policies, and institutions. These can be divided into three categories: Management of resources, Management of water services, and Management the necessary balance between supply and demand. Management of water resources refers to the management of rivers, lakes, and groundwater. It includes water allocation, assessment and protection from pollution, natural and man-made infrastructure, and groundwater discharge to maintain, distribute and store water-related ecosystems and water quality. Water service management extends from the water supplier to the end user's demand. Management of balancing supply and demand also involves a wide range of socio-economic interests, administrative activities related to allocation, authorization, and agreements (Tortajada and Biswas, 2009).

Sub-Saharan Africa in general, and Ethiopia in particular, face significant water challenges (UNEP, 2002). While Ethiopia has relatively adequate water resources that are technically and economically viable, the majority of the population lacks proper sanitation and hygiene facilities and access to clean water. Public drinking water is supplied from unprotected lakes, rivers, wells, ponds, and streams that are unsafe and most likely highly polluted (EWNHS, 2018).

\section{MATERIALS AND METHODS}

\section{The study area}

The Federal Democratic Republic of Ethiopia is a landlocked country in the Horn of Africa. Ethiopia is bordered by Eritrea and Djibouti to the north, Somalia to the east, Kenya and Somalia to the south, and Sudan and South Sudan to the west. The country has an area of $1,127 \mathrm{~km}^{2}$, including a water area of 7,444 $\mathrm{km}^{2}$, with an altitude ranging from 4,550m (Ras dejan mountain) to $125 \mathrm{~m}$ (Dalol depression) below sea level (EWNHS, 2018). According to World Bank (2019), the country has ten (as of 2020) autonomous regions and two city administrations (Addis Ababa and Dire Dawa) (Figure 1). The regional states and city administrations are divided into sub-regions. With a population of 
more than 110 million, the country comprises more than 80 ethnic groups and as many languages and religions.

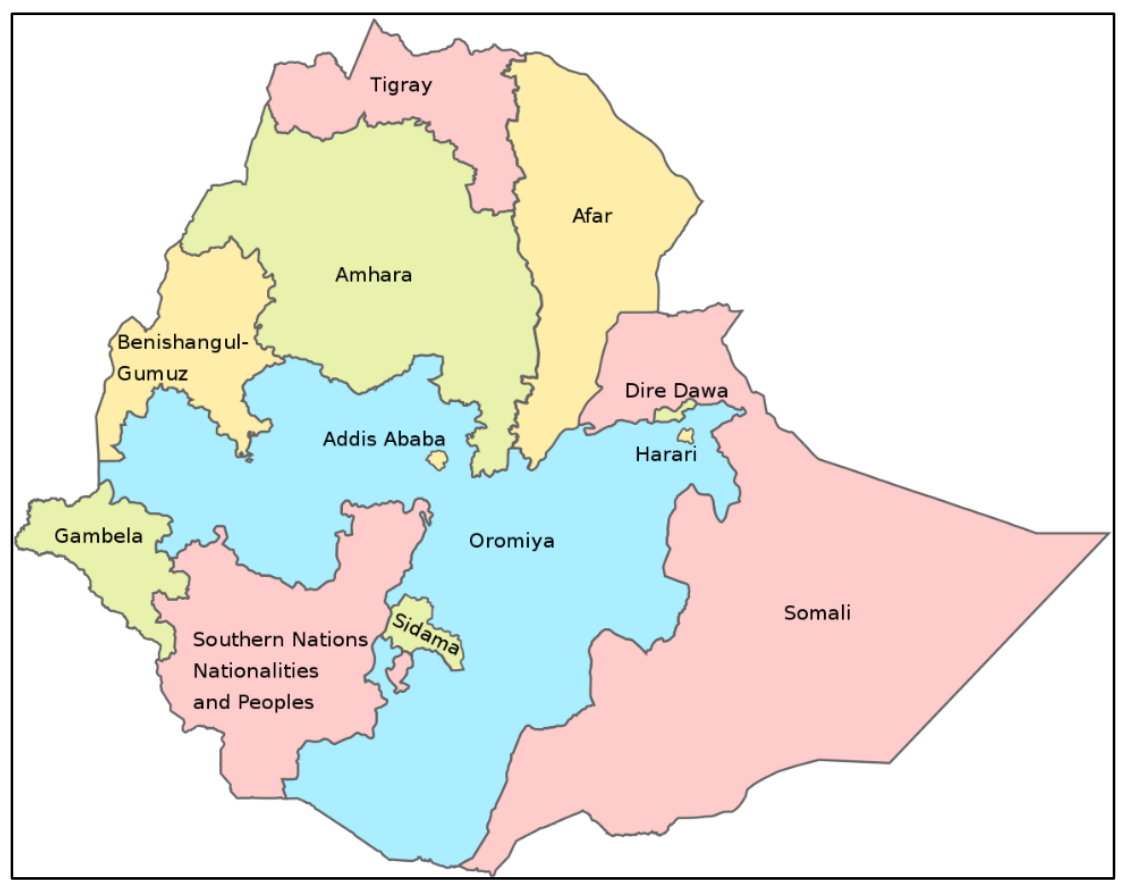

Figure 1. Ethiopia's political and administrative map (Anonymous, 2020)

\section{Methodology}

The necessary primary data for this study were collected from various sources. For this purpose, field observations and interviews were conducted between January and March 2019. During the interviews and field observations at Oromia Mining and Water Bureau, Awash Basin Authority, Adama City Water Bureau, Koka Water Supply Centre, and other interrelated agencies, the following main topics were discussed. The general status of water resources, regulations, policies, coordination among different stakeholders and sectors, and most importantly the problems of water management were discussed. Other qualitative data were obtained from interviews and observations. The data collected during the field observation and interview was also written in a holistic approach.

\section{RESULTS AND DISCUSSIONS \\ Water Status in Africa}

Africa has enormous potential water resources that can be harnessed and help to achieve the Sustainable Development Goal that the UN has set for the world by 2030. Although Africa is rich in water resources with major rivers such as the Nile, Congo, and Lake Victoria (Figure 2), many African countries still face difficulties in utilizing water resources due to economic and political problems. According to UNEP (2002), it is estimated that millions of Africans will face serious water shortages by 2030 unless the necessary investments are not made and measures taken in time. 


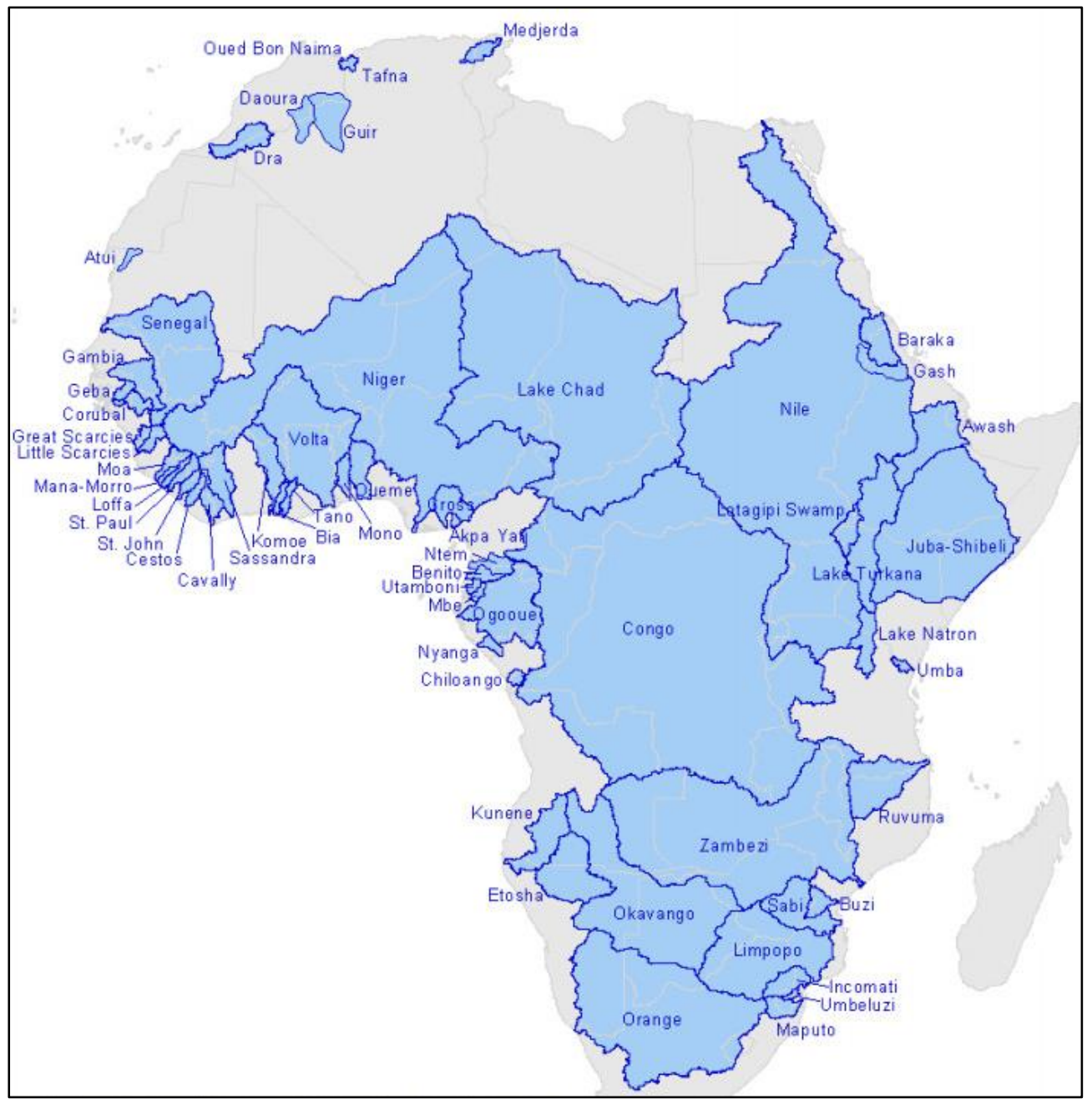

Figure 2. Africa's largest river basins (UNEP, 2002).

Africa is the second driest and most populous continent in the world. Poverty is also a widespread issue in Africa except a few regions. The majority of the continent's population lives in rural areas where there is no access to potable water, inadequate sanitation, and hygiene. The average annual per capita water availability is far below the global average of $6,498 \mathrm{~m}^{3} /$ person/year (Table 1). In Ethiopia, access to safe drinking water is 57 percent and improved sanitation remains woefully low at only 28 percent nationwide (UNEP, 2002).

Table 1. Global distribution of freshwater resources (UNEP, 2002)

\begin{tabular}{lccc}
\hline \hline Continent/Region & $\begin{array}{c}\text { Annual volume } \\
\left(\mathbf{k m}^{\mathbf{3}}\right)\end{array}$ & $\begin{array}{c}\text { Percentage of fresh } \\
\text { water resources } \mathbf{( \% )})\end{array}$ & $\begin{array}{c}\text { Per capita } \\
\left(\mathbf{m}^{\mathbf{3}} / \mathbf{y e a r}\right) \mathbf{2 0 0 8}\end{array}$ \\
\hline World & 43,802 & 100 & 6498 \\
Africa & 3931 & 9.0 & 4008 \\
Asia & 12393 & 28.3 & 3037 \\
South America & 12380 & 28.3 & 32165 \\
Central America and the & 781 & 1.8 & 9645 \\
Caribbean & & & \\
North America & 6877 & 15.7 & 15166 \\
Oceania & 892 & 2.0 & 32366 \\
Europe & 6548 & 14.9 & 8941 \\
\hline \hline
\end{tabular}

\section{Potential and Current Situation of Water Resources in Ethiopia}

Ethiopia has 12 major river basins, 11 lakes, 9 salt lakes, 4 crater lakes, and more than 12 major swamps (Figure 3). The average annual flow of the river basins is estimated to be 122.19 billion $\mathrm{m}^{3}$. With this enormous flow of its water resources, Ethiopia is called the "water tower of East Africa". 
This does not necessarily mean that it has abundant water resources that are easily accessible for use. Although Ethiopia has relatively adequate water resources (about 124 billion $\mathrm{m}^{3}$ of surface water, 2.6 billion $\mathrm{m}^{3}$ of groundwater, and hydroelectric potential of $161,000 \mathrm{Gwh} / \mathrm{year}$ ), only a portion of this enormous potential has been harnessed to contribute meaningfully to the socio-economic development of the country (MoWR, 2002).

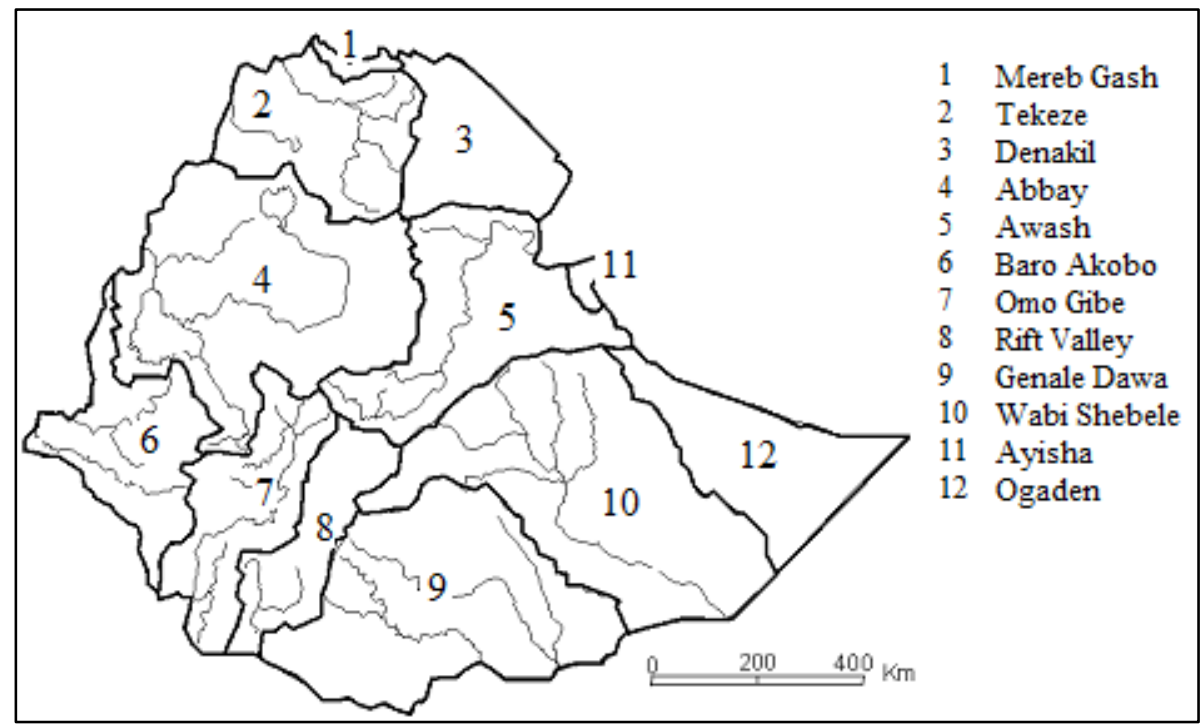

Figure 3. Major basins of Ethiopia (EWNHS, 2018)

Even the estimated 2.6 billion $\mathrm{m}^{3}$ of groundwater widely dispersed in the lowlands of the country could not be properly utilized stemming from financial and technical capacity problems. The findings of the research revealed that the majority of the country's population has access to ponds, springs, swamps, streams and rivers, and rainwater for domestic use. Water consumption per capita varies from 10-20L/day in some urban areas to 3-4 liters per person in rural areas. An estimated $86 \%$ of all water withdrawals in the country are used for agricultural purposes, $13 \%$ for domestic use, and $1 \%$ for industry, compared to global averages of $70 \%, 11 \%$, and $19 \%$, respectively (CIA, 2019).

\section{Nile River}

The Nile is a basin with a drainage area of 2.9 million $\mathrm{km}^{2}$, which makes up $10 \%$ of the entire African continent and is shared by nine countries (Burundi, Egypt, Ethiopia, Kenya, Rwanda, Tanzania, Sudan, Uganda, and Zaire). The basin takes its name from the main watercourse of the basin, the Nile. The Nile, the longest river in the world, has a length of $6825 \mathrm{~km}$ from the equator in Africa to the Mediterranean Sea (Figure 4). 


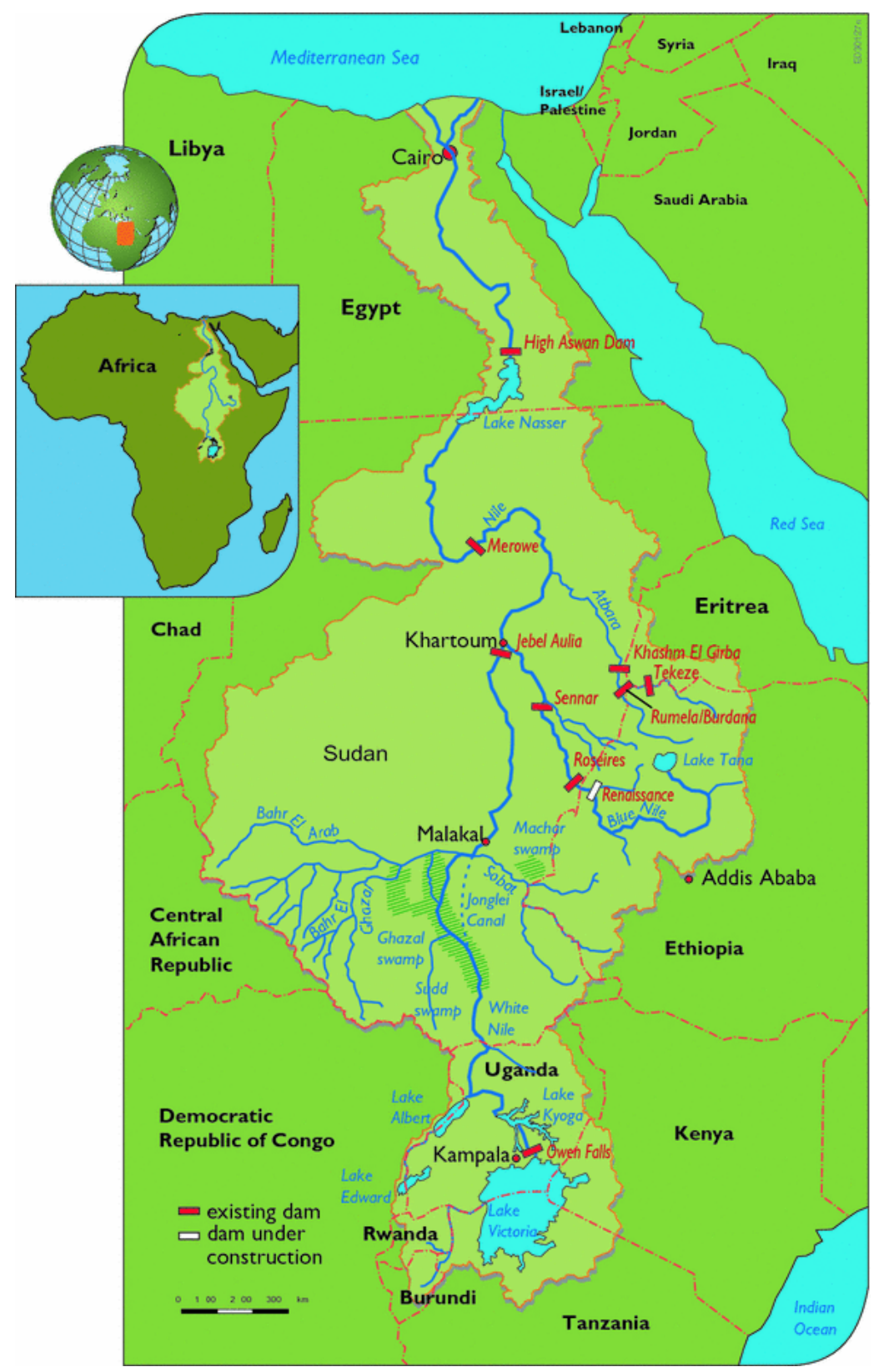

Figure 4. The Nile River (Loucks \& Van, 2017)

As it flows towards South-North, it takes most of its source from Lake Tana, Ethiopia. The annual volume of water supplied to the Nile from Ethiopia is about 72 billion $\mathrm{m}^{3}$, which is about $72 \%$ of the total river flow. The Upper Nile, also known as White Nile, originates from the equatorial lakes, particularly Lake Victoria and the largest freshwater swamp in the world (Sudd). The Nile then takes the Atabara River at Khartoum and there is no further major water inlet until it reaches the Mediterranean Sea (Bilen, 1997).

\section{Nile River Treaties and Water Rights of Upstream Countries}

According to the protocol signed in 1891 between Italy on behalf of Ethiopia and the British Colonial Administration in Egypt, Ethiopia was not allowed to build any hydraulic structures on the Blue Nile that would alter the amount of water flowing into the Nile River. Then, on May 15, 1902, the agreement was concluded between Ethiopia and the British colonial administration that defined the boundaries of Ethiopia. Through this agreement, the Ethiopian administration committed not to build any infrastructures that would alter the flow and volume of the Nile River to Egypt (Bilen, 2009).

With the Tripartite Agreement signed between Britain, France, and Italy on 13 May 1906, the notes were exchanged in Rome in 1925 between Italy and England. In addition, Egypt's interests in the Nile were reaffirmed without regard to the rights of the riparian states in the upper basin. The Nile Water 
Agreement of May 1929 is of particular importance for the water policy of the Nile. The most important article of the agreement makes it clear that no irrigation, power, or other development activities should be undertaken in Sudan and other countries under the British administration that would reduce or retard the amount of water flowing into Egypt. In 1935, an American company obtained permission from the Ethiopian government to build a dam at the outlet of Lake Tana. However, this initiative was stopped by England based on the agreement signed in 1929 (Bilen, 1997).

The Nile River Agreement (1959) provides no water allocation for the countries in the upper basin of the river. This inequitable allocation (see Table 2) still causes serious disputes in the region; especially between Ethiopia, the largest contributor to the Nile River (72\%), and Egypt, the largest user $(55 \%)$. The old colonial system, the British and French colonial periods, has left deep traces in the legal arrangements of the Nile. The protocols and notes supporting this agreement were signed in 1959 between Egypt and Sudan after the 1929 treaty that regulated the Nile's use regime. Even worse, the articles of the agreement include the following:

Except for the annual water allocations to Egypt and Sudan, the provisions of the 1929 agreement were adopted without much change.

Sudan agreed to the construction of the Aswan Dam, with part of the reservoir remaining in its territory.

Of the total annual volume of water that would flow into the Aswan Dam, Egypt (55.5 billion cubic meters) and Sudan (18.5 BCM) would each receive a share. Provided Sudan meets its quota, the construction of Roseries Dam and other facilities would be approved by Egypt.

Before construction could begin, all countries remaining in the upstream part of the Nile Basin had to apply and receive approval by submitting the relevant technical details to the joint technical committee formed by Egypt and Sudan.

Sudan could take measures to reduce water losses in the marshes and wetlands in the south of Sudan by agreeing with Egypt.

Table 2. Allocation of the Nile River according to 1959 Treaty (Bilen, 1997)

\begin{tabular}{lcc}
\hline Country & $\begin{array}{c}\text { Country's contribution to water } \\
\text { potential }\left(\text { Billion } \mathbf{~ m}^{\mathbf{3}}\right)\end{array}$ & $\begin{array}{c}\text { Water allocation according to the } \\
\mathbf{1 9 5 9} \text { Treaty }\left(\text { Billion } \mathbf{~ m}^{3}\right)\end{array}$ \\
\hline Egypt & 0 & 55.5 \\
Sudan & 0 & 18.5 \\
Ethiopia & 72 & 0 \\
Other Countries & 12 & 0 \\
Evaporation Losses & - & 10 \\
Total & 84 & 84 \\
\hline \hline
\end{tabular}

Analyzing (Table 2), it can be seen that the highest shares of the contribution to Nile River were supplied by Ethiopia. However, the lowest share was consistently provided by Egypt and Sudan, which were allocated the highest share for utilization. The 1959 agreement did not provide for the allocation of water to other riparian states, including Ethiopia, whose highlands contribute about $72 \%$ of the flow to the river basin.

To intermit Egypt's violation of international transboundary water law and to achieve effective and reasonable use of transboundary water resources with riparian states, fair regional cooperation and agreements should be reached, taking into account the principles (geographical, hydrographical, climatic, ecological, and natural) of international and regional agreements. Above all, the bilateral agreements (the 1929 Treaty Anglo-Egyptian and its modified version, the 1959 agreement), which completely disregarded water allocation to other riparian states, should be reconsidered with the participation of all states under international transboundary water law. In this way, it is possible to halt Egypt's aggressive approach to the use of the Nile and introduce a strong resolution as soon as possible.

\section{Water Ownership and Usage Rights}

On 8 July 1997, the General Assembly of UN adopted the Decision on the Non-Navigational Use of International Waterways. Looking at the Nile Rivers, Sudan was in favor of an agreement, Egypt and Ethiopia abstained, and Burundi was also against the agreement. This suggests that both upstream 
and downstream countries are unlikely to sign the convention and are unwilling to resolve disputes over transboundary water issues (Varis et al., 2008). In addition, Ethiopia's stance on the use of the Nile River in recent years and Egypt's stance on the allocation of the river could complicate the existing tensions over the use of the river.

Ethiopia's water policy and water rights declaration make it clear that surface and groundwater resources located within the country's geographic, ecological and natural boundaries are the common property of the Ethiopian people and the state. Under the national laws of the country and international conventions, every Ethiopian citizen has the right to access clean water for basic needs (FNGoE, 2000). Accordingly, the country must allocate and use its water resources in a sustainable manner to achieve a nationwide supply of clean water.

According to NGoE (1994), Article 44 of the Ethiopian Constitution, which is still in force and was adopted in 1995, states that all international agreements and relations entered into, established, or conducted by the state shall protect and ensure Ethiopia's right to sustainable development (FDRE, 1995). In addition, the Constitution clarifies that all-natural resources (including water) are the common property of the Ethiopian people and the state. The Ministry of Water, Irrigation, and Energy (MoWIE) is responsible for the overall planning, development, management, use, and protection of the country's water resources, as well as the supervision of all medium and large irrigation projects. However, the country still lacks strict enforcement of natural resource use regulations, coordination weaknesses, and adequate authorized institutions.

\section{PROBLEMS AND SOLUTION APPROACHES}

\section{Rapid Population Growth}

During the period between 2005 and 2050, the world population is expected to increase in only eight countries. The largest population increases are expected in the countries of India, Nigeria, Pakistan, Congo, Ethiopia, USA, Bangladesh, and China. Together, they may account for almost half of the expected growth in the world population during this period (Biswas et al., 2008).

In many regions of Ethiopia, the majority of the population lives in areas where water availability is limited and not easily accessible. With this rapid population growth, it is obvious that the major water resource issues will emerge to hinder the country's water policy. While the Ethiopian population was about 80 million in 2009, it is currently (2019 estimate) 110 million people (Figure 5).

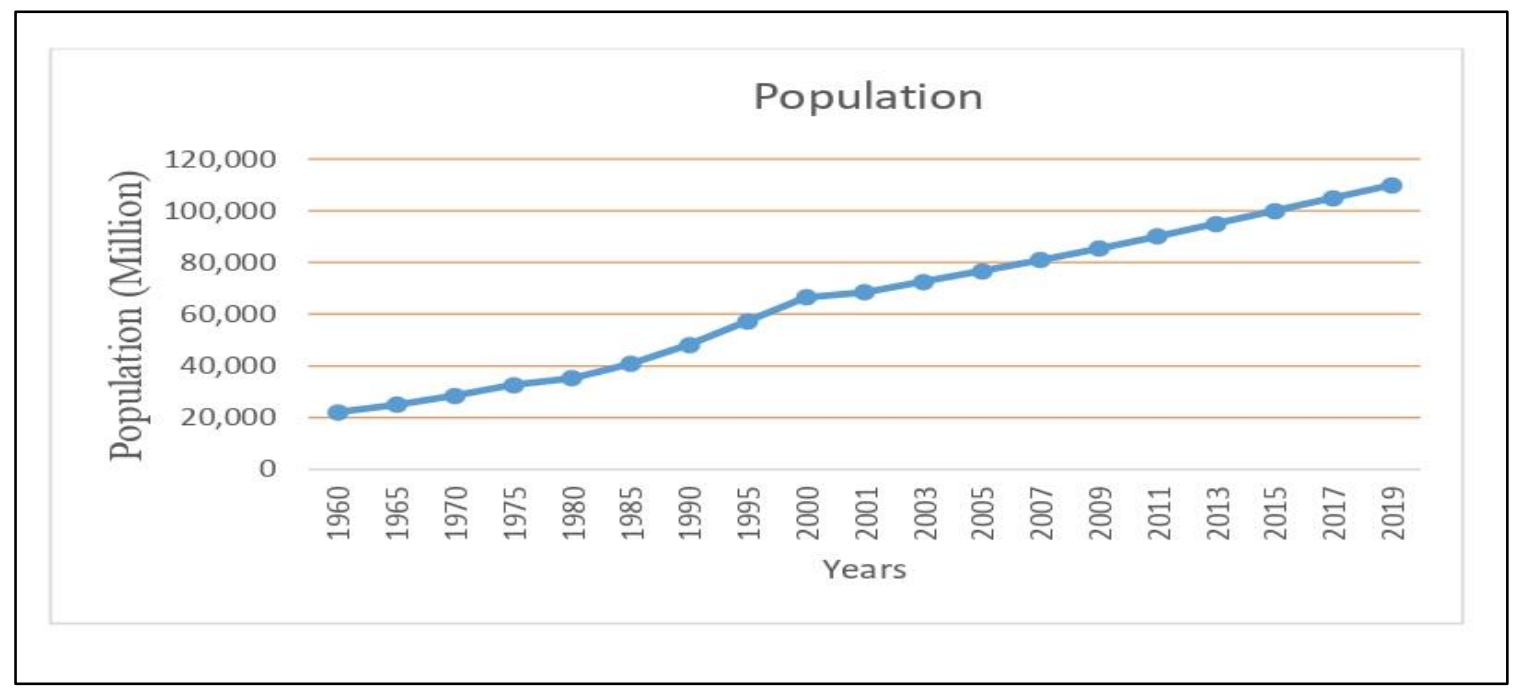

Figure 5. Population growth in Ethiopia between the years 1960-2019 (World Bank, 2019).

Extreme population growth is one of the most pressing reasons for water problems in Ethiopia. Excessive population growth, together with climate change, exacerbates the country's water scarcity problems. For example, while the country's population was about 60 million in 2000, it will reach almost 110 million people in 2019 (see Figure 5). This leads to many constraints in water supply and social stability. As the country's population grows, the demand for water or pressure on limited water resources is expected to increase. Population growth, uncontrolled urbanization, the release of 
untreated sewage and bulk waste into the environment and water bodies, and lack of treatment technologies are increasing the pollution of the country's water bodies.

\section{Hydropolitical Problems}

Ethiopia is a country endowed with huge hydroelectric potential. It is second only to Congo in hydroelectric potential in Africa. However, the country has so far exploited only a part of this potential. Due to inadequate environmental and water resources policies, the distribution and management of transboundary water resources create instability within and between riparian states (MoWR, 2002).

In this case, the Grand Ethiopian Renaissance Dam has been under construction since 2011 due to disputes over water policy issues regarding the filling and operation of the dam between Ethiopia and Egypt. The latest round of talks between Ethiopia and Egypt involving Sudan was held in Khartoum, the capital of Sudan, on September 15-16, 2019. However, no satisfactory agreement was reached on the duration of filling the reservoir of the dam. While Egypt wanted the reservoir to be filled in a period of 7 to 10 years so as not to restrict the flow in the river, Ethiopia rejected this plan and opted for three years (Anonymous, 2019).

Additionally, while Egypt wants the dam to release at least 40 billion cubic meters of water per year, Ethiopia has not specified how much should be released in this regard. After many years of diplomatic intercourse between Cairo and Addis Ababa, the US proposed mediation to reach a cooperative, sustainable, and mutually beneficial agreement on the filling and operation of the dam. The agreements signed by other countries on behalf of Ethiopia are a violation of its rights and should be revised immediately. The issue should be reassessed and the causes of disagreement between Egypt and Ethiopia should be resolved diplomatically.

\section{Financial Problems}

Due to the location of major rivers and lakes in the rugged physical structure, hydrological and topographical features of the country, sufficient investment is required for the optimum utilization of the country's water resources. On the other hand, in developing countries like Ethiopia, where surplus budgetary resources are used more for areas such as education and health than for water resources utilization, sufficient budgetary resources and investments have not been allocated for mega water infrastructure projects for water resources development. For this reason, there is insufficient funding from corporate financiers and private investors in the long run. Problems in the country's financial management, inadequate capital stock, and external debt pressures (China, Russia, USA, etc.) have generally made it difficult to raise and use national and international finance for water resources development.

\section{Technical Problems}

Stemming from the variability of climatic, topographic, and local conditions of water resources, the country needs a variety of hydrologic data. Regular hydrological data and information on the country's water resources are few or non-existent. The existing hydrological monitoring stations cover only $40 \%$ of the country (MoWR, 2002). Due to limited research and the unavailability of data, hydrological information on river basins in the country cannot be verified and estimated to use appropriate models and plans. There is no adequate advanced national research center and development institute specialized in water science to assess the water resources problems. The underutilization of the country's water resources has led to poverty, food insecurity, loss of biodiversity and conflict. Strengthening the role of applied research can be one of the solutions to alleviate the problems in the water sector (Awulachew et al., 2007).

\section{Political and Security Problems}

The Ethiopian people have been living in tragedy over the past decades due to an undemocratic regime, growing Bereacracy, misuse of regional resources, corruption, and unfortunately ethnically based disputes over the allocation and use of natural resources. Ethiopia consists of a population of about 110 million and about 83 ethnic groups with different identities, cultures, religions, and languages. In addition to this fact, superfluous conflict among stakeholders over the use of natural resources leads to waste of resources and growing animosity among people instead of being a strong pluralistic and economically vibrant nation. Moreover, the government's attitude of putting its own political affairs above the stability and economic growth of the country is hindering the establishment of a democratic government and the implementation of competitive reforms in the country. For this reason, the country is undergoing a deep transition. Investment opportunities in the country are being 
hampered and most of the projects that have been started are currently suspended. For instance, although the Ethiopian Renaissance Dam project was supposed to be completed in five years, it has been under construction since 2011. Reconciliation between ethnic groups and political parties and the implementation of meaningful reforms, including the revision of the country's water policy, would bring dramatic changes that would also allow the country's untapped natural resources to be managed.

\section{Water Pollution Problems}

Water pollution is a major challenge that degrades water quality especially in the 21 st century (Teshager et al., 2016). Another major problem is meeting the ever-increasing needs of rapid population growth, urbanization, industry, and agriculture. Land-use changes are known to have a significant impact on water quality by altering the concentration of nutrients (Stonestrom et al., 2009; Schlesinger et al., 2006) and sediment balance (Valentin et al., 2008). For example, the agricultural sector has a consumption share of about 86\% (CIA, 2019), which often reduces the normal flow in several rivers in the country.

Freshwater degradation is a result of the overall socio-economic development of human activities. Anthropogenic factors such as wastewater disposal, rapid population growth, excessive water abstraction, and traditional irrigation practices are likely to have huge impacts on groundwater storage and the other hydrological processes within a river ecosystem (Wada et el., 2013). Agricultural activities pose a major threat to the country's water bodies as they can cause algal blooms through nutrient and sediment pollution. It was observed that Lake Zuway, one of the most important lakes in Ethiopia, has significant pollution as untreated sewage is discharged directly into the lake and fertilizers used in agriculture end up in the surrounding lakes. As a result, the overall situation of water quality management in the country is far from satisfactory.

\section{SOLUTION APPROACHES}

\section{Wastewater Treatment}

Due to the lack of wastewater treatment technologies, water pollution is becoming an increasing problem in many parts of the country. The future social and economic development of the country is at great risk if water pollution is not regulated through sustainable water resource management (Libhaber and Jaramillo, 2012). Therefore, the country should adopt wastewater treatment plants and comprehensive water management policies and practices to improve water quality on the one hand and to ensure the availability of water in nature on the other.

Wastewater treatment is not only used for specific end-use, but also helps to ensure the health and standard of living of the community, which prevents pollution of the environment and water bodies (Biswas et al, 2009). Therefore, the government should take strict measures including issuing regulations and proclamations to create a harmonious environment and ensure the reclamation of rivers, lakes, and other water bodies. In the near future, desalination of the country's saline lakes and brackish water is likely to be the upcoming approach. This approach could be considered as an alternative source for irrigation and industrial purposes.

\section{Management of Transboundary Water Resources}

In the twenty-first century, international concern about the management and allocation of freshwater has increased worldwide. The issue of effective management and development of transboundary water resources has not been easily resolved in international forums due to intense debates and disagreements over national sovereignty concerns (Varis et al, 2008). To protect the rights of riparian states to transboundary waters and prevent disputes, the international community has proposed international general principles for the management of transboundary water resources. According to the article of agreement, the most important principle is to take into account the geographical, hydrographical, climatic, ecological, and natural character of transboundary water resources (Varis et al, 2008; Schelwald-van der and Reijerkerk, 2009). Therefore, Ethiopia should fully utilize its transboundary water resources under the international principles and agreements on the use of transboundary water resources with full rights and participate in the international water rights negotiations equipped with adequate preparations.

\section{Integrated Water Resources Management and a Rational Water Allocation and Allocation Management}

Integrated Water Resources Management (IWRM) promotes the coordinated development and management of water, land, and related resources to ensure economic and social well-being without 
compromising the sustainability of vital ecosystems, and provides for the joint management of all different uses of water resources (Asit, 2008). Incompetencies and weak coordination among institutions responsible for watersheds significantly hinder the implementation of the approach in the country. Therefore, the government should prioritize projects related to water issues in a wellorganized system that ensures comprehensive water resource management to overcome these challenges. In this regard, water problems can be solved through proper multi-disciplinary, multiinstitutional, and multi-stakeholder coordination (Asit, 2008; Schelwald-van der and Reijerkerk, 2009).

According to Rowan (2009), the European Union (EU) Water Framework Directive (WFD) exists as the most comprehensive water policy dedicated to promoting sustainable management of water resources. Its policies and legislation aim to protect natural habitats, keep air and water clean, ensure appropriate waste disposal, avoid toxic chemicals and contribute to sustainable development worldwide. In this regard, improving institutional capacity and strengthening regional measures to use and protect its transboundary water resources will benefit from implementing the holistic approach and the most comprehensive water policy (as the EU Water Framework Directive) at the national and regional levels in Ethiopia.

\section{Development of Multi-purpose Dams}

In ancient times, dams were built for a single purpose, namely, water supply or irrigation. As civilizations developed, greater needs arose for water supply, irrigation, flood control, navigation, water quality, sediment control, and power. Therefore, dams are built for specific purposes such as water supply, flood control, irrigation, navigation, sediment control, and hydroelectric power. A dam is a cornerstone for the development and management of the water resources of a river basin (Scudder, 2012). Multipurpose dam projects have also been implemented in many developing countries and regions (GAP/Southeastern Anatolia Project, Ataturk Dam in Turkey (Bilen, 2009), Bhakra Nangal in India and High Aswan Dam in Egypt (Biswas et al, 2009).

Because of such benefits and justifications, Ethiopia has so far implemented a few of its dams for such purposes. Accordingly, multipurpose dams are of great importance to developing countries like Ethiopia so that the community can derive domestic and socio-economic benefits from a single investment. Multipurpose dams, properly planned, designed, and implemented, will radically increase the use of water resources to the highest possible level. These projects will promote the socioeconomic development of the country and effectively regulate river flows and floods. In addition, they will also improve water quality and protect the ecosystem.

\section{Water Quality Management and Pollution Control}

The Ethiopian standards specify the physical, chemical, and bacteriological requirements of water for drinking and domestic purposes. The requirements contained in the standards are in line with the World Health Organization (WHO) and International Organization for Standardization (ISO) (ES, 2013). However, there is no integrated set of rules that expresses the desire to protect the ecosystem and preserve the freshwater quality of the country. Therefore, this standard should also include environmental management, technology, development, and society in a broader sense. Accordingly, integrated water quality monitoring and monitoring strategy have significant importance in maintaining or improving quality, controlling pollution, and protecting ecosystems. Therefore, it is crucial to assess water use in domestic, industrial, and agricultural sectors to meet the increasing challenges to freshwater resources (Wada et al., 2013). In addition, regular water quality monitoring and surveillance activities should be conducted on a planned and continuous basis. Public education programs that create awareness about climate change, the importance of water, water pollution, its causes and ways to prevent water pollution are of great importance.

\section{CONCLUSION}

Ethiopia has coped with the water resources utilization activities carried out so far with very low performance. Ethiopia, which is considered the water tower of East Africa due to its enormous transboundary water resource potential, has become marginalized and incompetent in deciding its transboundary water issues. In the country, the organizational structure for water resources management is very centralized, and sectoral coordination and stakeholder participation in allocation and decision making is unsatisfactory. Inconsistent water policies, technical problems, inadequately trained manpower and failure in financing and utilization of water resources are major impediments to 
the overall socio-economic development of the country. Therefore, the issue of sustainable water management should be supported by the entire society, including scientists, water professionals, development experts, policymakers, administrators, the public, non-governmental organizations (NGOs), and industrialists. Pursuing meaningful reforms in the use of water resources, including transboundary water allocation policies and reviewing inappropriate contracts signed in the past, would bring about dramatic political and economic changes and contribute significantly to managing the country's untapped natural resources. Most importantly, the commitment to implement holistic approaches and constructive mechanisms in policy and practice will significantly improve the development and transformation of Ethiopia's water resources utilization strategy. As such, Ethiopia needs to establish a rigorous legal framework for the realization of its national objectives related to the use of its water resources.

\section{REFERENCES}

Anonymous, (2019). Impacts of the dam. https://www.voanews.com/usa/trump-meets-egypt-ethiopia-sudanfmsabout-dam-feud

Anonymous, (2020). Regions of Ethiopia. https://en.wikipedia.org/wiki/Regions_of_Ethiopia

Asit K. Biswas., (2008). Integrated Water Resources Management: Is It Working? International Journal of Water Resources Development, 24:1, 5-22.

Awulachew, S. B. Yilma, A. D. Loulseged, M. Loiskandl, W. Ayana, M. \& Alamirew, T. (2007). Water resources and irrigation development in Ethiopia. Vol. 123.

Bilen, Ö. (1997). Turkey and water issues in the Middle East. Southeastern Anatolia Project (GAP) Regional Development Administration.

Bilen, Ö. (2009). Ortadoğu su sorunları ve Türkiye. TESAV, Toplumsal, Ekonomik, Siyasal Araştırmalar Vakfi.

Biswas, A. K., Tortajada, C., \& Izquierdo-Avino, R. (Eds.). (2009). Water management in 2020 and beyond. Berlin: Springer.

Central Intelligence Agency (CIA), (2019). The World Fact Book. https://www.cia.gov/library/publications/theworld-factbook/

ES, 2013. Ethiopian Standards. 261:2001. National Drinking Water Quality Monitoring and Surveillance Strategy Ministry of Health. Addis Ababa, Ethiopia.

EWNHS, (2018). Ethiopian Wildlife and Natural History Society and Wetlands International, A First Directory of Ethiopian Wetlands: Descriptions, Ecosystem Services, Causes of Degradation \& Recommendations for Restoration and Sustainability. Eclipse Printing and Graphics.

FDRE, (1995). Constitution of the Federal Democratic Republic of Ethiopia. Federal Negarit Gazetta, 1(1), 4045.

FNGoE, (2000). Ethiopian Water Resources Management, Proclamation No: 197/2000.Federal Negarit Gazeta of Etiopia.

Libhaber, M. \& Jaramillo, A.O., (2012). Sustainable Treatment and Reuse of Municipal Wastewater. IWA Publishing.

Loucks, D. P., \& Van Beek, E. (2017). Water resource systems planning and management: An introduction to methods, models, and applications. Springer.

MoWR, (2002). Ministry of Water Resource. Water Sector Development Program. Main report II.

NGoE, (1994). Proclamation to Provide for The Utilization of Water Resources. Proclamation No. 92/1994, Negarit Gazeta of the Transitional Government of Ethiopia.

Prasifka David W., (1994). Water Supply Planning. Kreiger publishing company.

Rowan, C. (2009). The politics of water in Africa: the European Union's role in development aid partnership. Vol. 24. IB Tauris.

Schelwald-van der Kley, A. L., \& Reijerkerk, L. (2009). Water: A way of life: Sustainable water management in a cultural context. CRC Press.

Schlesinger, W.H., Reckhow, K.H., Bernhardt, E.S., 2006. Global change: the nitrogen cycle and rivers. Water Resources Research. 42 (3).

Scudder, T. T. (2012). The future of large dams: Dealing with social, environmental, institutional and political costs. Taylor \& Francis.

Stonestrom, D.A., Scanlon, B.R., Zhang, L., 2009. Introduction to special section on impacts of land use change on water resources. Water Resources Research 45 (7).

Teshager, A.D., Gassman, P.W., Schoof, J.T., 2016. Assessment of impacts of agricultural and climate change scenarios on watershed water quantity and quality, and crop production. Hydrol. Earth Syst. Sci. 20 (8), 3325 UN-WBCSD, 2006. WBCSD Report on Facts and trends of water. ISBN: 2-940240-70-1. Switzerland.

Tortajada, C.\& K Biswas, A., (2009). Water Resources Development and Management. Springer. 
UNEP, (2002). United Nations Environment Programme. Vital water graphics: an overview of the state of the world's fresh and marine waters. Earthprint.

UNEP, (2010). United Nations Environment Programme. Africa Water Atlas. ISBN: 978-92-807-3110.

Valentin, C., Agus, F., Alamban, R., Boosaner, A., Bricquet, J., Chaplot, V., De Guzman, T., De Rouw, A., Janeau, J., Orange, D., 2008. Runoff and sediment losses from 27 upland catchments in Southeast Asia: impact of rapid land use changes and conservation practices. Agriculture, Ecosystem \& Environment 128 (4), 225-238.

Varis, O., Tortajada, C., \& Biswas, A. K., (2008). Management of transboundary rivers and lakes. Springer.

Veettil, A.V., Mishra, A.K., 2016. Water security assessment using blue and green water footprint concepts. Jouranl of Hydrology. 542, 589-602.

Wada, Y., Van Beek, L.P., Wanders, N., Bierkens, M.F., 2013. Human water consumption intensifies hydrological drought worldwide. Environmental Research Letters. 8, 034036.

World Bank, (2019). Population total, Ethiopia. https://data.worldbank.org/indicator/SP.POP.TOTL?locations=ET

WWAP, (2012). World Water Assessment Programme. The United Nation World Water Development Report 4: Managing Water Under Uncertainty and Risk. UNESCO. 